ARTIGO

\title{
Origens e direção do Pragmatismo Ecumênico e Responsável (1974-1979)
}

MATIAS SPEKTOR*

Rev. Bras. Polít. Int. 47 (2): 191-222 [2004]

\section{Introdução}

Em 19 de março de 1974, o presidente Ernesto Geisel, recém indicado, reuniu o novo ministério para anunciar que as estruturas do regime autoritário iniciado em 1964 seriam flexibilizadas sob seu controle pessoal. No mesmo dia, o presidente batizou a política externa de seu governo de Pragmatismo Ecumênico e Responsável. Durante os cinco anos subseqüentes, Geisel dedicou à política externa e a seu chanceler, Antônio Francisco Azeredo da Silveira, mais horas de despacho do que a qualquer outra pasta. Juntos, o presidente e o chanceler buscaram transformar aspectos importantes do comportamento e da palavra do Brasil no mundo. Três décadas após a sua formulação inicial, a referência explícita ao pragmatismo volta a aparecer no vocabulário normativo da diplomacia brasileira, moldando os termos do debate sobre os rumos internacionais do país.

Utilizando fontes primárias recentemente disponibilizadas para pesquisa, este artigo aponta as precondições intelectuais e materiais, as tensões de origem e os primeiros mecanismos de implementação do Pragmatismo Ecumênico e Responsável. O trabalho é desenvolvido

\footnotetext{
* Doutorando em Relaçóes Internacionais na Universidade de Oxford.
} 
em cinco etapas. Em primeiro lugar, esta introdução passa em revista a literatura existente, as fontes documentais disponíveis, assim como o direcionamento geral e as causas do pragmatismo. Em seguida, apresentase uma interpretação dos contextos intelectual e material em que a noção de pragmatismo ganhou vida. $\mathrm{Na}$ sequiência, enfoca-se a trajetória e o pensamento de Azeredo da Silveria. Em quarto lugar, situa-se a política externa do pragmatismo no marco do projeto político do presidente Geisel. Por fim, trata-se, sinteticamente, da reforma organizacional que o novo governo promoveu no Ministério das Relações Exteriores a partir de 1974.

\section{Literatura e fontes}

O conhecimento existente sobre a política externa do pragmatismo tem crescido rapidamente nos últimos anos. Numerosos trabalhos acadêmicos enfocam o período específico. ${ }^{1}$ Outros situam o quinqüênio

\footnotetext{
${ }^{1}$ COSTA, Gino. Brazil's foreign policy towards her neighbours during the Geisel years. 1986. Tese (Doutorado) - Universidade de Londres, Londres; LIMA, Maria R. S. de. The political economy of Brazilian foreign policy: nuclear policy, trade and Itaipu. 1986. Tese (Doutorado) - Vanderbilt University; PINHEIRO, Letícia. Foreign policy decision-making under the Geisel government: the president, the military and the foreign ministry. 1994. Tese (Doutorado) - London School of Economics and Political Science, Londres; MIYAMOTO, Shiguenoli. Do discurso triunfalista ao pragmatismo ecumênico (geopolítica e política externa no Brasil pós-64). 1995. Tese (Doutorado) - Universidade de São Paulo, São Paulo; LIGIERO, Luis F. Politicas semelhantes em momentos diferentes: exame e comparação entre a politica externa independente (1961-1964) e o pragmatismo responsável (1974-1979). 2000. Tese (Doutorado) - Universidade de Brasília, Brasília; FERREIRA, L. F. A politica latino-americana do Governo Geisel. 1993. Tese (Mestrado) - PUC, Rio de Janeiro; SARAIVA, Miriam. A opção européia no marco do Pragmatismo Responsável. 1994. Tese (Mestrado) - PUC, Rio de Janeiro; LESSA, Antônio C. Brasil, Estados Unidos e Europa Ocidental no contexto do nacional desenvolvimentismo: estratégias de diversificação de parcerias, 1974-1979. 1994. Tese (Mestrado) - Universidade de Brasília, Brasília; SPEKTOR, Matias. Ruptura e legado: o colapso da cordialidade oficial e a construção da parceria entre o Brasil e a Argentina (1967-1979). 2002. Tese (Mestrado) - Universidade de Brasília, Brasília; FONSECA, Gelson. Mundos diversos, argumentos afins: aspectos doutrinários da política externa independente e do pragmatismo responsável. In: FONSECA, Gelson. A legitimidade e outras questōes internacionais. São Paulo: Paz e Terra, 1998, p. 293-352; LIMA, Maria Regina Soares de \& MOURA, Gerson. A trajetória do pragmatismo: uma análise da política externa brasileira. Dados. 25, 3, 1982, p. 349-363; LESSA, Antônio C. A diplomacia universalista do Brasil: a construção do sistema contemporâneo de relações bilaterais. Revista Brasileira de Política Internacional, Brasília, ano 41, 1998, p. 29-41; LESSA, Antônio C. A vertente perturbadora da política externa durante o governo Geisel: um estudo das relaçóes Brasil-Estados Unidos. Revista de Informação Legislativa, 35, 137, 1998.
} 
Geisel em perspectiva de longa duração. ${ }^{2}$ Já há, também, algumas memórias e biografias de figuras-chave do período. ${ }^{3}$ Para fins de contextualização, existe uma recente literatura sobre o fim do regime militar. O presidente Geisel e seu governo têm recebido crescente atenção à medida em que novas fontes são disponibilizadas ao público. ${ }^{4}$ Em relação à figura de Silveira, o comentário positivo de seus auxiliares

${ }^{2}$ CERVO, Amado L. (org.) O desafio interancional. Brasília: Editora Universidade de Brasília, 1994; ALBUQUERQUE, José G. (org.). Crescimento, modernização e política externa. Sessenta anos de politica brasileira: 1930-1990. São Paulo: Cultura, 1996; BANDEIRA, Moniz. Estado nacional e politica internacional na América Latina: o continente nas relaçôes Argentina-Brasil: 1930-1992. Brasília: Editora Universidade de Brasilia, 1995; BANDEIRA, Moniz. Relaçôes Brasil-Estados Unidos no contexto da globalização: a rivalidade emergente. São Paulo: Senac, 1999; BANDEIRA, Moniz. O eixo Argentina-Brasil: o processo de integraçāo da América Latina. Brasília: Editora Universidade de Brasília, 1987; CAMARGO, Sonia \& OCAMPO, José. Autoritarismo e democracia na Argentina e no Brasil: uma década de política exterior. São Paulo: Convívio, 1988; DANESE, Sérgio F. Diplomacia presidencial. Rio de Janeiro: Topbooks, 1999; VIZENTINI, Paulo F. A política externa do regime militar brasileiro. Porto Alegre: UFRGS, 1998; CERVO, Amado L. \& MAGALHÃES, José. C. de. Depois das caravelas: as relaçôes entre Portugal e Brasil: 1080-2000; SOMBRA SARAIVA, José F. O lugar da África: a dimensão atlântica da politica externa brasileira: de 1946 a nossos dias. Brasília: Editora Universidade de Brasília, 1996; HURRELL, Andrew. The quest for autonomy: the evolution of Brazil's role in the international system: 1964-1985. 1986. Tese (Doutorado) - University of Oxford; MELLO, Leonel I. Brasil, Argentina e a balança de poder regional: equilíbrio, preponderância ou hegemonia? (1969-1986). 1991. Tese (Doutorado) - Universidade de São Paulo, São Paulo; GONÇALVES Williams da S. \& MIYAMOTO, Shiguenoli. Os militares na política externa brasileira: 1964-1984. Estudos Históricos, 6, 12, 1993, p. 211-246; FERREIRA, Oliveiros S. As forças armadas como instrumento de política externa. Política e Estratégia, 4, 4, 1986.

3 CORRÊA, Pio. O mundo em que vivi. São Paulo: Expressão e Cultura, 1995; CAMPOS, Roberto. Lanterna na popa. São Paulo: Companhia das Letras, 1994; CASTRO, Celso \& D’ARAUJO, Maria C. (orgs.) Ernesto Geisel. Rio de Janeiro: Fundação Getúlio Vargas, 1997; BARBOZA, Mário Gibson. Na diplomacia, o traço todo da vida. Rio de Janeiro: Record, 1992; CAMILIÓN, Oscar. Memóprias politicas, de Frondizi a Menem: 1956-1990. Buenos Aires: Planeta, 1999; GUERREIRO, Saraiva. Lembranças de um empregado do Itamaraty. São Paulo: Siciliano, 1992; FALCÃO, Armando. Geisel: do tenente ao presidente. Rio de Janeiro: Nova Fronteira, 1995; CUNHA, Vasco Leitão da. Diplomacia em alto mar. 2. Edição, Rio de Janeiro: Fundação Getúlio Vargas, Brasília: Funag, 2003.

${ }^{4}$ O'Donnell et alii. Transiçôes do regime autoritário: primeiras conclusões. São Paulo: Vértice, 1987; ALVES, Maria H. M. State and opposition in military Brazil. Austin: University of Texas Press, 1985; LINZ, Juan J. The future of an authoritarian situation or the institutionalization of an authoritarian regime: the case of Brazil. In: STEPAN, Alfred (ed.) Authoritarian Brazil. New Haven: Yale University Press, 1973, p. 233-254; GÓES, Wálder de. O Brasil do general Geisel. Rio de Janeiro: Nova Fronteira, 1978; CAMARGO, Aspásia \& GÓES, Wálder de. O drama da sucessão. Rio de Janeiro: Nova Fronteira, 1984; e GASPARI, Elio. A Ditadura Derrotada. São Paulo: Companhia das Letras, 2003. 
contrasta com as acusações de seus desafetos. ${ }^{5}$ Lamentavelmente, ainda há poucas informações sobre sua visão de mundo, já que ele não deixou diários ou notas sistematizadas.

De forma geral, esse conjunto de obras talvez faça do pragmatismo um dos períodos mais estudados da história das relações internacionais do Brasil. Paradoxalmente, entretanto, esse também é um dos períodos menos mapeados da atuação internacional do Brasil no pós-Segunda Guerra Mundial: faltam estudos historiográficos detalhados sobre as principais vertentes da atuação externa do país, sobre as causas do pragmatismo, sobre a sua base teórica e conceitual, sobre a posição do país na sociedade internacional dos anos 70 e sobre os paralelismos entre o pragmatismo brasileiro e o comportamento de outros países em desenvolvimento de porte médio que, naquele momento histórico, também ensaiaram políticas externas mais assertivas (por exemplo, África do Sul, Índia, Indonésia, Irã, México e Paquistão).

À medida em que a abertura dos arquivos oficiais evolui, tornase possível re-avaliar o período desde novas perspectivas. O material primário agora disponível surpreende por seu volume e qualidade. Silveira doou sua coleção privada de documentos à Fundação Getúlio Vargas, que a abriu para pesquisa no fim da década de 1990, junto com uma série de entrevistas gravadas entre 1979 e $1982 .{ }^{6}$ Da mesma maneira, lá encontram-se depositados os papéis do presidente Geisel, embora estes não sejam críticos para a compreensão de sua política externa. ${ }^{7}$ Apesar das recentes mudanças restritivas no marco regulatório de acesso a arquivos oficiais brasileiros, o pesquisador também conta com

\footnotetext{
${ }^{5}$ Ver o contraste, por exemplo, entre Palestras proferidas no Instituto Rio Branco em homenagem ao ex-chanceler Azeredo da Silveira. Brasília: 15 maio, 2000. (disponíveis em: <http://www.mre. gov.br/irbr>) com BANDEIRA, Moniz. Estado nacional..., op. cit., p. 235, CAMPOS, Roberto. Prefácio. In: BANDEIRA, Moniz. Relaçôes Brasil-Estados Unidos no contexto da globalização: a rivalidade emergente. São Paulo: Senac, 1999, e MELO, Ovídio de A. O reconhecimento da Angola pelo Brasil em 1975. Comunicação \& Política, maio/ago, 2000, p. 75-133.

${ }^{6}$ Para uma descrição do acervo ver http://www.fgv.br/cpdoc. SILVEIRA, Antônio Francisco Azeredo da. Depoimento. Rio de Janeiro: CPDOC, 1979/1980/1982, 2000. 22 tapes (20h 55'). A seguir, Depoimento.

7 Ver PINHEIRO, Letícia. O pragmatismo responsável no arquivo do presidente Geisel. In: CASTRO, Celso \& D’ARAUJO, Maria Celina (orgs.). Dossiê Geisel. Rio de Janeiro: Fundação Getúlio Vargas, 2002, p. 75-88.
} 
o acervo do Arquivo Histórico do Ministério das Relações Exteriores, em Brasília. Finalmente, as chancelarias estrangeiras de importantes parceiros do Brasil e, notavelmente, as bibliotecas presidenciais norteamericanas, têm liberado materiais relevantes sobre a década de 1970 a passo acelerado. ${ }^{8}$

\section{Natureza e direção do pragmatismo}

Muito do comentário sobre a política externa do governo Geisel interpreta o período como um movimento de crescente independência, autonomia e 'flexibilidade' em relação aos estreitos limites impostos pela estrutura do sistema internacional da Guerra Fria. Livrava-se o Brasil da pecha do alinhamento automático aos desígnios do poder hegemônico hemisférico, os Estados Unidos. Assim, o pragmatismo seria uma expressão da tentativa brasileira de ganhar maior espaço de manobra em um sistema dominado pelas grandes potências. Tal movimento teria sido possível graças a mudanças estruturais no sistema internacional entre as décadas de 1960 e 1970 - o declínio relativo da capacidade militar dos Estados Unidos face à União Soviética, a incorporação da China continental ao equilíbrio global de poder, a inusitada força dos países produtores de petróleo via Organização dos Países Exportadores de Petróleo (Opep), a voracidade do movimento de descolonização na África e na Ásia e suas repercussões na composição da ONU, o debate militar norte-americana no Vietnã, e a emergência da Europa e do Japão como novos centros de poder econômico.

A tônica do pragmatismo - e seu elemento mais distintivo - foi a aproximação da política externa ao projeto normativo de tradições realistas de política internacional. Assim, a diplomacia dos anos Geisel valeu-se, mais ou menos explicitamente, de conceitos e valores típicos do realismo político. A lista de exemplos é extensa: a noção de que o país movia-se em um sistema cujas partes estão estrategicamente interconectadas (por exemplo, a decisão brasileira de utilizar o programa de visitas de Estado de Geisel à Europa Ocidental como instrumento de

\footnotetext{
${ }^{8}$ Em particular a Biblioteca Presidencial Gerald Ford, o Nixon Presidential Materials do National Archive Records e a Biblioteca Presidencial Jimmy Carter.
} 
barganha nas negociações com os Estados Unidos); a crença, refletida em atitudes políticas concretas, de que o país podia, efetivamente, transcender suas circunstâncias históricas, melhorar seu posicionamento relativo na estrutura internacional de poder e, assim, ganhar mais responsabilidade e autoridade no cenário internacional (por exemplo, as decisões de Brasília em relação à África Negra); a adoção, ao menos retórica, da ética da prudência e da autocontenção (por exemplo, a decisão de acrescentar os qualificativos 'ecumênico' e 'responsável' à noção de pragmatismo); o abandono de posturas absolutas em relação à potência hegemônica (nesse período abandona-se, conscientemente, a oposição retórica típica do Brasil do pós-Segunda Guerra mundial entre a completa abdicação e a total rejeição aos desígnios de Washington - nas palavras do chanceler, o Brasil e os Estados Unidos passavam a ter uma relação mais 'madura' à medida que o Brasil transformava-se em um país de 'calças compridas'). Entretanto, a explícita utilização de elementos do projeto realista conviveu com a tradicional ideologia brasileira de política externa. Como será evidenciado abaixo, a integração entre essas duas vertentes enfrentou problemas e deixou muitas perguntas sem respostas. Seus resultados são instigantes tanto do ponto de vista teórico como da perspectiva da política externa comparada.

Hoje, sabe-se que muito do pensamento estratégico associado à política externa do governo Geisel precedeu a posse do novo governo em março de 1974 - alguns de seus antecedentes apareceram nos anos da Política Externa Independente (1961-1964) e nos governos dos generais Costa e Silva (1967-1969) e Médici (1969-1974). Há linhas oriundas do Estado Novo (1937-1945) e da gestão de Juscelino Kubitschek (1956-1961). Em perspectiva de longa duração, os anos Geisel situam-se confortavelmente na tendência geral a maior e mais veloz asserção da autonomia nacional face aos estritos limites impostos pelo sistema internacional da Guerra Fria. Visto dessa maneira, o pragmatismo coincide com o auge do modelo brasileiro de diversificação de parcerias.

Onde reside, então, o elemento de inovação? A novidade do pragmatismo encontra-se, acima de tudo, no tratamento dos vínculos com os principais relacionamentos do país. É possível detectar transformações importantes em todas as áreas relevantes da agenda 
externa: no relacionamento com os EUA, com a Bacia do Prata, com os países andinos, com a Europa, a África, o Oriente Médio, a China e o Japão. Nos casos de Argentina, Israel e Portugal, as medidas tomadas nos anos pragmatismo colidiram com práticas de longa tradição no repertório da diplomacia brasileira. Adotaram-se, também, novos posicionamentos na Organização dos Estados Americanos (OEA) e na Organização das Nações Unidas (ONU). Além disso, o pragmatismo trouxe novos elementos de estilo e de retórica do discurso diplomático. Este é um período de redefinições importante e, em certos casos, sistemáticas, do comportamento brasileiro no ambiente internacional.

\section{Causas}

A produção intelectual existente sobre o pragmatismo aponta três conjuntos de causas, localizadas no nível as estruturas, das idéias e da agência de indivíduos-chave. Em primeiro lugar, como indicado acima, a década de 1970 assistiu a modificações significativas na estrutura internacional de poder que facilitaram a projeção de certos países em desenvolvimento. Em segundo lugar, circulavam idéias inovadoras sobre a capacidade desses países emergirem na cena internacional e ganharem autonomia face às grandes potências, assim como na habilidade do Terceiro Mundo de introduzir uma agenda global de justiça redestributiva e reforma do ordenamento econômico internacional. Finalmente, a literatura entende que a categoria de homem de Estado (ou liderança política) ganha relevo especial ao se tratar do pragmatismo. Assim, o fato de Geisel e Silveira haverem comandado a política externa teria feito toda a diferença, moldando a natureza e a direção das mudanças ocorridas. A nova documentação disponível parece reforçar a visão de que as origens do pragmatismo foram multicausais e, mais especificamente, materiais, intelectuais e de liderança individual.

\section{Antecedentes: origens do projeto de poder}

Esta seção descreve e analisa a evolução da ideologia da política externa brasileira no período imediatamente prévio ao pragmatismo. Trata-se de um momento importante porque nessa época começaram a 
ganhar contorno os temas centrais da política externa da segunda metade da década de 1970. Encontram-se lá as primeiras manifestações de que o sistema internacional cederia lugar a um Brasil ascendente caso o país tivesse a coragem de ousar: "As soluçōes medíocres e pequenas não convêm nem interessam ao Brasil. Temos de pensar grande e planejar em grande escala, com audácia de planejamento". ${ }^{9}$ Tal visão encontrava eco no comentário estrangeiro sobre o Brasil, que descrevia o país como potência emergente, potência média ou potência regional. ${ }^{10}$ Por outro lado, em finais da década de 1960 também ganhava contorno a vertente econômica da asserção externa do Brasil. Além disso, o país definia o tipo de poder que pretendia adquirir, especificava a natureza do seu projeto revisionista no mundo e, ao fazê-lo, trazia à superfície muitas das tensóes que iriam caracterizar os anos do pragmatismo.

As bases materiais do perfil brasileiro ao longo dos anos 60 e 70 apontavam, com nitidez, em direção ascendente. Entre 1961 e 1980, o produto interno bruto brasileiro triplicou-se. Entre 1968 e 1973, a economia cresceu, em média, $11 \%$ ao ano sem inflação significativa, um logro somente alcançado, desde o fim da Segunda Guerra mundial, pelo Japão. Pela primeira vez, o Brasil assistia à criação de um mercado doméstico massificado e o crescimento econômico, pelo menos nos anos 70 , não era acompanhado por um aumento da desigualdade de renda. A estratégia brasileira de desenvolvimento outorgava ao Estado a principal responsabilidade pela elevação do produto interno bruto mediante a

${ }^{9}$ CONFERÊNCIA DE ARAÚJO CASTRO NO COLÉGIO INTERAMERICANO DE DEFESA. Washington D.C. 11 dez 1970.

${ }^{10}$ SCHNEDIER, Ronald. Brazilian foreign policy: a case study in upward mobility. Interamerican Economic Affairs, 27, 4, spring 1974, p. 3-25; LANDRY, David M. Brazil's new regional and global roles. World Affairs, 137, summer 1974, p. 23-37; ROETT, Riordan. Brazil ascendant: international relations and geopolitics in the late $20^{\text {th }}$ century. Journal of International Affairs, 9, 2, Fall 1975, p. 139-154; PERRY William. Contemporary Brazilian foreign policy: the international strategy of an emerging power. Foreign policy papers, 2, 6, Beverly Hills, California: Sage Publications, 1976; ROETT, Riordan (ed.) Brazil in the seventies. Washington: American Enterprise Institute for Public Policy Research, 1976; GALL, Norman. The Rise of Brazil. Commentary. Jan 1977; SCHNEIDER, Ronald. Brazil: foreign policy of a future world power. Boulder, Colorado: Westview, 1977; BROOKE, Jim. Dateline Brazil: southern superpower. Foreign Policy. Fall 1981, 167-180; SELCHER, Wayne (ed.). Brazil in the international system: the rise of a middle power. Boulder, Colorado: Westview, 1981; YOUNG, Jordan. Brazil: emerging world power. Malabar, Florida: Robert Krieger, 1982. 
substituição de importações e o domínio de processos industriais cada vez mais sofisticados. As empresas estatais aumentaram sua participação no investimento total do país de 3\% em 1963 para 22\% em 1979. Os produtos manufaturados, que eram responsáveis por $5 \%$ da pauta de exportaçóes em 1964, passaram a representar 36\% em 1971. Ao mesmo tempo, o café minguava de $55 \%$ para $13 \%$. As exportações cresceram de US\$ 1,5 bilhões para US\$ 6,2 bilhões entre 1967 e 1973, em razão de $24 \%$ ao ano. Contudo, a participação brasileira nos fluxos de comércio internacional permaneceu negligível, oscilando entre 0,9\% e 1,75\% no período 1969-1974. As importações, por sua vez, cresceram à razão de $27 \%$ anuais. Esses desenvolvimentos andavam da mão da estratégia de diversificação de mercados externos. Entre 1969 e 1974, o peso dos Estados Unidos na pauta de exportações brasileiras declinou (de 26,4\% a $21,9 \%$ ), assim como o da Europa (de $46,2 \%$ a 37,4\%). Em tendência oposta, o Japão cresceu de 4,6\% a 7,8\% e as exportaçôes para o Terceiro Mundo e o mundo socialista foram elevadas de $21,5 \%$ a 30,3\% (a África, por exemplo, passou de 1,05\% a 5,24\%). ${ }^{11}$

A forma pela qual o surto de crescimento econômico traduziu-se em política externa foi, entretanto, peculiar.

Em primeiro lugar, os principais motes utilizados pelo governo de Emílio G. Médici (1969-1974) tinham caráter assertivo e falavam ao mundo - Brasil potência, Ninguém pára este país e a ambição de Grandeza. Entretanto, cumpriam, acima de tudo, a função doméstica de descomprimir críticas internas à política repressiva do regime militar. Não é possível encontrar efeitos ou reflexos precisos na prática diplomática, da retórica da grandeza.

Em segundo lugar, a lógica do projeto de desenvolvimento nacional ecoava duas teorias de economia política internacional que raras vezes são encontradas ao mesmo tempo em um mesmo país. Por um lado, havia vozes mercantilistas segundo as quais o comércio de uma nação constitui a base essencial de seu poder político e de sua projeção diplomática. Por outro, ouviam-se vozes dependentistas para as quais o sistema internacional cristalizava e reproduzia desigualdades históricas,

${ }^{11}$ Ver IBGE. Estatísticas históricas do Brasil: séries econômicas, demográficas e sociais de 1550 a 1988. Rio de Janeiro: IBGE, 1990 e HURRELL. The Quest... op. cit., p. 145. 
privando aos países mais pobres da possibilidade de desenvolver-se plenamente. Era como se o coro brasileiro incluísse as vozes de List e Colbert por um lado, e as de Marx e Prebisch por outro. É devido a essa mistura de duas correntes distintas do pensamento econômico que o caso da industrialização brasileira não encontra paralelos fáceis com as tradições estatistas das industrializações norte-americana, alemã, russa ou japonesa. Era na interseção entre os poderes redentores do Estado e da desigualdade estrutural entre as nações que o Itamaraty concebia a participação brasileira no comércio internacional como instrumento de asserção nacional. ${ }^{12}$

Em terceiro lugar, apesar da retórica da potência emergente, o Brasil do período mantinha-se fiel aos princípios do realismo dos fracos: a política externa enfatizava o pacifismo, o não-intervencionismo, a autodeterminação e a segurança coletiva. O país de Médici, assim como o faria o de Geisel, continuava abraçando o direito internacional como escudo contra as pressões das grandes potências e desconfiando da celebração de tratados entre desiguais. Assim, a política externa não se queria estacionária nem revolucionária: sua abordagem era moderadamente revisionista. ${ }^{13}$

Qual era a lógica do revisionismo brasileiro? Desde meados da década de 1960, o discurso diplomático brasileiro argumentava que o status quo internacional funcionava em detrimento do Brasil e, portanto, devia ser reestruturado. O problema, dizia-se, residia no fato de que, para as grandes potências, o equilíbrio de poder equivalia à ausência de confrontos nucleares e reduzia-se a ela. Tal postura, afirmavam os brasileiros, era contrária aos interesses das nações mais fracas, para as quais uma estrutura global de paz apenas surgiria da combinação entre segurança e desenvolvimento econômico e social. ${ }^{14}$ Criticava-se, assim, a 'coexistência pacífica' e a política

\footnotetext{
12 Para uma visão histórica das teorias do Equilíbrio de Comércio ver HASLAM Jonathan. No virtue like necessity: realist thought in international relations since Machiavelli. New Haven: Yale University Press, 2002; para a idéia de que a política externa brasileira pode ser interpretada sobre um diálogo imaginário entre Maquiavel e Marx ver HURRELL, Andrew. The theory of Brazilian foreign policy. Mimeo: 1998; para uma explicação das teorias dependentistas ver LOVE, Joseph L. Economic ideas and ideologies in Latin America since 1930. In: BETHELL, Leslie (ed.). Ideas and ideologies in twentieth century Latin America. Cambridge University Press, 1996, p. 207-275.

${ }^{13}$ Ver CERVO. O desafio... op. cit.

${ }^{14}$ CASTRO Araújo. Palestra no Colégio Interamericano de Defesa. Washington D.C.: 14 maio 1969.
} 
de controle de armamentos típicas da détente por dividirem o mundo em esferas de influência, congelando a estrutura do sistema internacional e impossibilitando as nações mais fracas de alcançar seus desígnios nacionais. Nesse contexto, o propósito declarado da política externa brasileira era o de neutralizar todos os elementos do sistema internacional capazes de obstaculizar o potencial brasileiro de poder. ${ }^{15}$

Em termos práticos, durante a década prévia à chegada de Geisel ao poder, o Brasil deu os seguintes passos: como membro fundador da Unctad, defendeu a noção de segurança econômica coletiva; rejeitou o Tratado de Não-Proliferação Nuclear; passou, gradativamente, a apoiar o movimento de descolonização afro-asiático; argumentou, na ONU, a favor da transferência de $1 \%$ dos gastos militares globais para a promoção do desenvolvimento econômico internacional; manteve status de observador mas nunca associou-se completamente ao Movimento Não-Alinhado; mobilizou-se para uma reforma da Carta da ONU; somou sua voz à demanda terceiro-mundista por uma Nova Ordem Econômica Internacional; abandonou gradualmente seu apoio a Israel para aproximar-se do mundo árabe, fazendo o mesmo com a África do Sul do apartheid vis-a-vis a África Negra; extendeu seu mar territorial de três para duzentas milhas; vinculou noções de proteção ambiental às de desenvolvimento industrial; recusou a possibilidade de ocupar um assento rotativo no Conselho de Segurança da ONU, denunciando a intransigência das grandes potências; e, finalmente, rejeitou as medidas de controle populacional adgovadas pelo FMI, Banco Mundial e Assembléia Geral da ONU. ${ }^{16} \mathrm{Ou}$ seja, o Brasil aderiu à crescente crítica terceiro-mundista da ordem internacional, mas o fez sem adotar papel protagônico ou confrontacionista.

A medida exata do potencial brasileiro de poder permanecia incógnita. Mas havia indícios de que os instrumentos de que o Brasil poderia dispôr em sua trajetória ascendente não eram os mesmos utilizados por outros países médios à época, como a Índia e o Egito. No caso brasileiro, deparamos com aquilo que a literatura contemporânea

${ }^{15}$ CASTRO Araújo. Conferência no Colégio Interamericano de Defesa. Washington D.C.: $11 \mathrm{dez} 1970$.

16 Ver BUENO, Clodoaldo. A política multilateral brasileira. In: CERVO. O desafio..., op. cit., p. 59-144. 
chama de soft power. Trata-se de um modelo no qual o poder de um país não depende, exclusivamente, de suas capacidades materiais (indústria, recursos naturais, dimensões geográficas, exércitos e armamento). $\mathrm{O}$ foco recai, ao contrário, sobre a capacidade que o país tem de angariar apoios externos para os valores e posturas que propugna no meio internacional. $\mathrm{O}$ poder do país reside em sua habilidade para manipular o sistema internacional em seu favor. Para tanto, cabe à diplomacia nacional tirar proveito da interdependência entre as nações. Eis a lógica por trás das prioridades brasileiras de diversificação de mercados, da resistência em associar-se incondicionalmente ao Movimento Não-Alinhado e da complementação nítida no discurso diplomático do valor da ordem com o valor da justiça.

Daí segue que, durante os primeiros anos da década de 1970, a retórica brasileira passou a ser crescentemente permeada por expressões tais como distribuição, igualdade, equidade, proporcionalidade, discriminação, participação e inclusão. Essa tendência, entretanto, continha imprecisóes. Por vezes, a demanda brasileira por mais justiça era identificada com o princípio da igualdade (isto é, todas as partes devem receber prêmios e custos idênticos). Em outras ocasióes, contudo, a justiça era compreendida como compensação (isto é, as partes mais fortes devem utilizar seus recursos para indenizar os custos infligidos às mais fracas). Muitas vezes as duas noções apareciam fundidas. Assim, segundo a proposta da Nova Ordem Econômica Internacional, o desenvolvimento deveria ser considerado um direito universal e atingido mediante uma série de regras que levariam a concessóes recíprocas, mas também proporcionais. A tensão entre a justiça como igualdade e a justiça como compensação nunca chegou a ser completamente resolvida no discurso dos países periféricos. De tal sorte, nunca ficou completamente claro como é que a noção de justiça torna-se parte integrante da estabilidade e da ordem internacional. Isso talvez ajude a compreender por que, apesar da projeção do Terceiro Mundo durante as décadas de 1960 e 1970, faltaram propostas concretas e precisas sobre como reverter a injustiça global. ${ }^{17}$

\footnotetext{
${ }_{17}$ Ver MORTIMER, Robert A. The third world coalition in international politics. Boulder, Colo.: 1984; BHAGWATI, Jagdish N. \& RUGGIE, John Gerard. Power, passions, and purpose: prospects for North-South negotiations. Cambridge: 1984; SAUVANT: Karl P. The group of 77: evolution,
} 
Em quarto lugar, apesar da ênfase na interdependência, o realismo brasileiro que ganhava forma naquele período repetia o caráter defensivo de outrora, modernizando-o. Reafirmava-se a soberania, a autodeterminação e a não-intervenção contra o que era visto, desde Brasília, como um conjunto de normas internacionais cada vez mais intrusivas. A crítica da expansão da vertente normativa da comunidade internacional recaía no argumento, inusual e fascinante, de que apenas os países poderosos poderiam abdicar de aspectos de sua soberania sem comprometer a integridade de seus países. Os fracos ainda precisavam do escudo da soberania para proteger-se e, assim, poder crescer.

Afirma-se a necessidade do estabelecimento de alguns órgãos supranacionais, destinados a impor restriçôes e limitaçóes em assuntos como os da preservação do meio humano, população, não-proliferação, etc., argumentando-se que as novas condições do mundo tornam obsoletos e superados certos conceitos de soberania e independência. Ora, ninguém duvida de que o progresso das relações internacionais, para ser efetivo e duradouro, terá de assentar em certas premissas de interdependência e em certas bases supranacionais. Isso é evidente. O que sustentamos é que esse estágio de supranacionalismo e de interdependência pressupõe um estágio prévio de soberania e de total independência política e econômica (...) é, assim, perfeitamente compreensível que os países menores se agarrem a propósitos e princípios que, ainda que constante e repetidamente violados, os ajudam a defender-se de pressões políticas e diplomáticas (...) Evidentemente, os países maiores e mais fortes podem dar-se ao luxo de ser muito menos afirmativos em relação a sua soberania e a seu nacionalismo. ${ }^{18}$

Em retrospectiva, embora os anos prévios ao pragmatismo constituam um período de redirecionamento importante da política externa brasileira tradicional, o leitmotif da ideologia nacional - o perfil de potência emergente e a aspiração a um status mais elevado no concerto

structure, organization. New York: 1981; SINGH, J.S. A new international economic order. New York: 1977; REUBEN, Edwin (ed.). The challenge of the new international economic order. Boulder, Colo.: 1981. Ver também FOOT, Rosemary; HURRELL, Andrew; GADDIS, John Lewis. Order and justice in international relations. Oxford: Oxford University Press, 2003.

${ }^{18}$ CASTRO, Araújo. Conferência no Colégio Interamericano de Defesa. Washington D.C.: 11 dez 1970. 
internacional - não levou a uma revisão sistemática da política externa. O caráter dúbio do Brasil Potência revela um ideal nacional que era ambicioso mas vago, enraizado no surto do crescimento econômico e associado ao caráter repressivo do governo. Durante a gestão Médici, por exemplo, a crítica brasileira do ordenamento internacional manteve-se restrita aos foros multilaterais e de nenhuma maneira confrontou as preferências das grandes potências. Apesar da asserção retórica, a ideologia por trás do desenvolvimento brasileiro permaneceu, em grande parte, voltada para dentro e sem vertente internacional clara. ${ }^{19}$

Mas as incoerências da idéia de Brasil Potência não representavam um problema político relevante. $\mathrm{O}$ regime conseguia vitórias eleitorais impactantes para seu partido. ${ }^{20}$ Somente a partir de 1973 os fundamentos materiais e ideológicos desse quadro começaram a mudar. A crise internacional do petróleo escureceu as perspectivas do modelo econômico e, meses mais tarde, as urnas instalaram um clima de incerteza sobre a viabilidade do regime autoritário. Criavam-se as condições para que, em 1974, o novo governo pusesse a política externa à frente de seu projeto de poder.

\section{A formação de Azeredo da Silveira}

Durante os anos do Brasil Potência, Silveira estava envolvido numa das frentes mais delicadas da política externa - a embaixada em Buenos Aires. Uma panorâmica das posturas que lá tomou introduz os elementos essenciais de seu pensamento realista, suas proposiçóes mais poderosas, e seus problemas e ausências mais chamativos. Os anos na Argentina também dizem muito sobre a natureza e o escopo das inovações de Silveira em relação à política externa tradicional como um todo.

Antes, cabem breves comentários sobre sua trajetória política e caráter. Silveira nasceu em 22 de setembro de 1917, o quinto de sete

\footnotetext{
${ }^{19}$ Ver HURRELL, Andrew. Brazil as a regional great power: a study in ambivalence. In: NEUMANN, Iver. Regional great powers in international politics. London: St Martin's Press, 1992, p. 16-49.

${ }^{20}$ Para uma análise da coexistência entre eleições e regime autoritário ver METTENHEIM, Kurt von. The Brazilian voter: mass politics in democratic transition (1974-1986). Pittsburgh: University of Pittsburgh Press, 1995.
} 
filhos. Esta era uma família politizada: seu bisavô fora ministro dos Assuntos Estrangeiros na década de 1870 e, durante 25 anos, seu avô fora um político influente que participou várias vezes da Comissão Diplomática da Câmara. Seu pai era um parlamentar cuja oposição ao regime varguista terminou por levá-lo várias vezes à prisão. Isso teve grande impacto na vida do seu filho, que aos 14 anos deixou a elitista escola Anglo-Americana para reconciliar os estudos com o trabalho administrativo em um banco local. No banco ele cresceu rapidamente, tornando-se chefe de Departamento aos 20 anos. Mas sua impaciência com o estilo de vida estagnante do banco o levou a deixar o Brasil, em 1939, para uma permanência de 4 anos nos Estados Unidos. Lá trabalhou como oficial administrativo no consulado brasileiro em São Francisco. Em 1943, aos 26 anos, retornou ao Rio de Janeiro para ingressar à carreira diplomática. No curso de sete meses conheceu e casou-se com May Paranhos. Uma vez na carreira, somou-se aos Novos Turcos, um grupo de jovens profissionais que estavam em desacordo com a condução do ministério e discutiam alternativas doutrinárias. Duas décadas mais tarde, em 1964, Silveira foi elevado ao grau de embaixador, trabalhando como diretor da Divisão de Assuntos Administrativos, embaixador em Genebra e, depois, em Buenos Aires. Sua postura pouco convencional em relação à Argentina chamou a atenção do então presidente da Petrobrás, general Ernesto Geisel. Em 15 de março de 1974, aos 56 anos, Silveira atingiu rango ministerial no gabinete do presidente Geisel. Cinco anos mais tarde, findo o governo, Silveira chefiaria as embaixadas nos Estados Unidos (1979-1983) e em Portugal (1983-1985). Ele morria de câncer em 1990, aos 73 anos.

Muito do comentário sobre sua gestão descreve um caráter duro e militante. Corajoso, audacioso, persistente, tenaz, vivaz, cordial, charmoso, gênio criativo e respeitoso são alguns dos adjetivos recorrentes com os que ele é identificado. Excêntrico, louco, estridente, combativo, vingativo, mordaz e impetuoso também. O homem era adicto ao trabalho, expansivo na conversa, orgulhoso de seu próprio conhecimento em política externa e tinha obsessão por detalhe. Tinha ojeriza à falta de densidade analítica de muitos de seus colegas porque, por ele, tal superficialidade permitia ao burocrata justificar a sua inação perante os fatos. Não surpreende, portanto, que os critérios utilizados por Silveira 
para julgar um interlocutor fossem essencialmente intangíveis - estilo, perspicácia, caráter e vocação para a ironia. O gosto pelo intangível mais tarde seria insumo crítico para o desenvolvimento de uma singularíssima relação com seu colega norte-americano, Henry Kissinger. Um assunto pessoal era importante. Silveira e sua mulher tiveram quatro filhos. Em curto período, duas das filhas morreram tragicamente ao tempo em que seu pai chegava ao topo da carreira. Anos mais tarde, ele reconheceria que essa experiência lhe dera renovado vigor e coragem para suportar as vicissitudes do poder. Mais do que isso, ele acreditava que a dor da perda das filhas o pusera em posição privilegiada para lidar com o introspectivo presidente Geisel, cuja visão de mundo e estilo também haviam sido afetados pela perda de um filho moço em acidente trágico.

\section{A batalha formativa}

Em meados da década de 1960, as relações entre Argentina e Brasil azedaram em níveis até aquele momento desconhecidos. No centro da disputa, o controle das águas internacionais do Rio Paraná a partir da elaboração dos planos para a construção da represa brasileiro-paraguaia de Itaipu. ${ }^{21}$ No Brasil, o tema cindiu as opinióes em dois campos nitidamente opostos. De um lado, estavam aqueles que defendiam a prática histórica do Itamaraty - era mister acomodar os interesses brasileiros às demandas argentinas. Esse pensamento, herdeiro de tradições oriundas da diplomacia brasileira no Prata do século XIX, respeitava os moldes do realismo defensivo: era de interesse brasileiro tolerar o alto perfil da diplomacia argentina porque Buenos Aires era a única capital sulamericana capaz de mobilizar todo o subcontinente contra o Brasil; cabia ao Brasil buscar, sistematicamente, novas oportunidades de cooperação com a Argentina no intuito de desdramatizar a agenda bilateral e diluir faixas de atrito; ganhava o Brasil muito ao incluir a Argentina em suas iniciativas regionais e hemisféricas porque, ao fazê-lo, Buenos Aires sentiase parte do ordenamento regional e, assim, o legitimava; e, finalmente, tinha o Brasil um interesse natural em promover bons ofícios entre a

${ }^{21}$ Ver, por exemplo, MENDONÇA, Ariel M. de. A geopolitica e a politica externa do Brasil: a Ata das Cataratas e o equilibrio de forças no Cone Sul. 2004. Tese (Mestrado) - Universidade de Brasília, Brasília. 
Argentina e os Estados Unidos sempre que esses dois países entrassem em rota de choque - uma dinâmica recorrente nas relaçôes internacionais do hemisfério ao longo do século XX.22 Para esse grupo, a estratégia brasileira tradicional da cordialidade oficial em relação à Argentina era uma das causas principais de o Brasil nunca haver testado forças com o vizinho no campo de batalha. Um dos principais propositores dessa política, o embaixador Pio Corrêa, vaticinava: "Seria um erro fatal (...) pretender o Brasil acantonar-se em uma política de isolamento e de omissão ou, pior ainda, de obstrução ante a questão da Bacia do Prata” ${ }^{23}$

Do outro lado, e em oposição, emergiam vozes críticas à política tradicional do Brasil para seu vizinho austral. Não se tratava de um grupo organizado em torno a uma lógica única, nem contavam essas pessoas com o apoio e valor agregado de décadas de tradição. Entretanto, foram essas as visões que passaram a ganhar os sucessivos debates internos no Itamaraty. É nessas fileiras que Silveira, já nos primeiros meses de 1969 como novo embaixador em Buenos Aires, começou a alcançar notoriedade. A evolução do embate interno sobre a estratégia brasileira para a Argentina é fascinante e pode ser agora acompanhada em detalhe graças a novas fontes. ${ }^{24}$ Por que Silveira se opunha à acomodação? Aqui o pensamento realista de Silveira começa a ganhar contornos nítidos.

O consenso tradicional, na chancelaria, sobre a melhor forma de lidar com a Argentina era, em sua essência, um consenso sobre os

\footnotetext{
${ }^{22}$ Para uma síntese deste argumento ver SPEKTOR, Matias. O Brasil e a Argentina entre a cordialidade oficial e o projeto de integração. Revista Brasileira de Política Internacional, ano 45, v. 1, 2002, p. 117-145.

23 Pio Corrêa ao Ministério das Relações Exteriores (MRE), telegrama confidencial, Buenos Aires, 24 jan 1969, n. 349, Acervo Azeredo da Silveira (AAS), 1972 a 73. CPDOC/FGV (Fundação Getúlio Vargas).

${ }^{24}$ Os documentos-chave deste período são: Silveira ao MRE, telegrama confidencial, Buenos Aires, 21 mar 1970, n. 49, AAS, 1969.01.15. CPDOC/FGV; Silveira ao MRE, ofício-parecer, Buenos Aires, 10 maio 1971, n. 394, Arquivo Histórico do Ministério das Relações Exteriores em Brasília (AHMRE), caixa 17; Silveira ao MRE, ofício secreto, Buenos Aires, 23 jun 1971, n. 518, AHMRE, caixa 17; MRE à legação em Buenos Aires, telegrama secreto urgentíssimo, Brasília, 10 ago 1971, n. 599, AAS, 1969.01.15. CPDOC/FGV; Silveira ao MRE, telegrama secreto, Buenos Aires, 14 de julho de 1971, n. 1133, AAS, 1969.01.15.CPDOC/FGV; MRE à legação em Buenos Aires, telegrama secreto, Brasília, 22 jul 1971, n. 535, AAS, 1969.01.15. CPDOC/FGV; Gibson Barboza a Silveira, telegrama particular secreto urgentíssimo, Brasília, 10 ago 1971, AAS, 1969.01.15. CPDOC/FGV; e Silveira a Gibson Barboza, telegrama particular secreto urgentíssimo, Buenos Aires, 10 ago 1971, AAS, 1969.01.15. CPDOC/FGV.
} 
constrangimentos que o sistema sul-americano impunha ao Brasil. A postura defensiva em relação ao vizinho devia-se à percepção comum, durante boa parte do século XIX e mais da metade do século XX, de que a Argentina tinha capacidade de mobilização diplomática contra o Brasil no contexto sul-americano. Em 1969, entretanto, Silveira via mudanças importantes na distribuição regional de poder. A Argentina, ele argumentava, não mais ombreava o Brasil. Para ele, o declínio argentino abria caminho para um novo arranjo regional no qual o Brasil abandonaria sua posição acuada. Curiosamente, a análise de Silveira não estava assentada na argumentação clássica de certo pensamento realista segundo o qual o poder é mensurável em termos materiais. Ao contrário, e de acordo com noções brasileiras herdadas da época do Império, Silveira via o poder como um misto de capacidade financeira, pujança cultural e agilidade diplomática. Para ele, Buenos Aires havia perdido os elementos que outrora lhe permitiram atrair e manter estreitas amizades na América do Sul. Como muitos de seus antecessores, Silveira acreditava que a posição relativa de uma nação dependia mais de seu prestígio na sociedade internacional do que de sua força militar. O poder era, acima de tudo, um atributo social, sustentado por peso econômico. ${ }^{25}$

De que maneira e por que canais as mudanças no poder relativo das nações traduziam-se em modificações no status quo internacional? Essa é uma pergunta importante e atual porque tem recebido pouca atenção no pensamento teórico do realismo. Aqui, a história da política externa pode ajudar a esclarecer esses mecanismos. $\mathrm{Na}$ análise de Silveira, havia uma incongruência entre a estrutura sul-americana de poder (onde a Argentina não mais tinha meios materiais ou sociais para pressionar o Brasil como o fizera) e o comportamento das unidades (onde o Brasil dos tardios anos 60 continuava comportando-se como se a Argentina tivesse capacidade de pressioná-lo). O problema, Silveira deixava a entender em seus inúmeros despachos, era de percepções: os constrangimentos do Brasil na cena sul-americana eram auto-impostos. As amarras eram essencialmente intelectuais, acumuladas progressivamente ao longo das décadas. O Brasil precisava, portanto, livrar-se da sombra de sua própria tradição.

As propostas alternativas que Silveira apresentava evidenciam o conteúdo e substância de seu realismo, cujas características principais

25 Depoimento, 19, B, 30 jan 1980. 
podem ser encontradas, em maior ou menor grau, no passado da prática internacional do Brasil. Para ele, normas, acordos, tratados e convençôes internacionais eram importantes, mas apenas na medida em que agregassem valor à direção geral do interesse nacional. Assim, Silveira desenvolveu argumentos para convencer o Itamaraty de que a Declaração de Montevidéu - arcabouço legal assinado por Brasil e Argentina em 1933 para regular o uso de águas internacionais da Bacia do Prata - não mais era instrumental aos interesses brasileiros da década de 1970 e deveria, portanto, ser substituído. Assim, em sua visão de mundo as normas internacionais reduzem a incerteza e induzem as nações a convergir, mas não moldam as preferências nacionais. Elas regulam o interesse nacional, não o constitutem. Marcos normativos consolidam o status quo regional e devem, portanto, ser utilizados uma vez que os interesses nacionais estão plenamente satisfeitos, não antes.

Por outro lado, Silveira entendia que os países mais fortes da América do Sul estavam em posição de impôr a lei aos mais fracos, mas ganhavam muito se conseguissem fomentar o sentimento de inclusão entre os segundos. Muito da estratégia de Silveira para a Argentina era informado pela compreensão de que Brasília teria como deslocar Buenos Aires como o principal elo de Assunção, La Paz e Montevidéu. Tal mudança incluiria a oferta de crédito para a realização de obras de infra-estrutura e cooperação tecnológica (como com a Bolívia); a revisão de acordos tidos como desequilibrados pelos mais fracos (por exemplo, a revisão legal feita no governo Geisel sobre a administração da Lagoa Mirim com o Uruguai); a retificação de fatos considerados como injustiças históricas pelos menores (por exemplo, a devolução ao Paraguai, por Geisel, dos troféus de guerra obtidos pelo Brasil ao fim da guerra do século XIX); e a quebra do equilíbrio de poder sul-americano, a favor do Brasil (como indicado na justificativa brasileira para a proposta de um Tratado de Cooperação Amazônica). Ao tomar tais medidas, Silveira acreditava que o Brasil aumentava seu módico de poder social na região. ${ }^{26}$

Finalmente, em seus anos de formação, Silveira também explorou o princípio de que as preocupações econômicas e comerciais têm precedência sobre outras considerações. Apesar de haver recomendado que “(...) daqui por diante, qualquer aspecto de nossa política bilateral

${ }^{26}$ Ver documentação citada, para cada episódio, em SPEKTOR. Ruptura e legado. Op. cit. 
com a Argentina - desde o intercâmbio comercial até o recurso água, por exemplo - deve ser considerado não apenas em seus aspectos específicos, mas à luz das atuais diretrizes gerais do governo argentino (...)" $27, \mathrm{o}$ comércio bilateral durante sua gestão como embaixador em Buenos Aires e, depois, como chanceler, mais que duplicou.

Não causa surpresa que o primeiro encontro entre o futuro presidente Geisel e Silveira tenha girado em volta ao tema de uma nova estratégia regional. A noção de poder nacional articulada por Silveira em seus anos formativos iriam informar, ao longo dos anos do pragmatismo, as principais opções políticas do governo.

\section{A virada de Geisel}

Ao chegar ao poder em março de 1974, Ernesto Geisel e seu grupo haviam decidido iniciar um processo de liberalização política batizado de abertura. Assim como Gorbatchov o faria anos mais tarde, Geisel falava em uma transição do regime autoritário para uma situação vaga, nunca explicitada. Não se falava de uma transição do autoritarismo para a democracia. A noção de que a liberalização política no Brasil culminaria com um governo civil eleito pelo povo não ocorreu até muito mais tarde.

Por que liberalizar? A literatura especializada tem argumentado que a liberalização do sistema político foi uma estratégia liderada por uma facção do regime que pretendia preencher o vácuo entre o estabelecimento militar enquistado no aparelho de Estado e a sociedade brasileira. Ao fazê-lo, esse grupo tentava prevenir o distanciamento entre a elite militar governante e o corpo político nacional por um lado e, por outro, pôr fim às lutas internas entre facções militares rivais, tão comuns em regimes centralizados. Essas interpretações convergem para que a decisão de Geisel pela abertura gradual e controlada foi tomada autonomamente por ele, e não resultou de demandas da sociedade civil, nem do fim do ciclo de crescimento milagroso ou de pressões internacionais.

27 Silveira ao MRE, telegrama secreto urgentíssimo, Buenos Aires, 26 jul 1971, n. 1237, AAS, 1969.01.15. CPDOC/FGV. 
Em retrospectiva, a abertura incluiu: o progressivo fim da censura à imprensa, a redução do poder e independência da comunidade de informações, o abandono da prática das prisões políticas, fortalecimento da hierarquia militar, a anistia a exilados políticos e a imposição de uma nova lei eleitoral enviesada a favor do partido governante. Essa agenda coexistiu com o uso político da tortura e do terrorismo de Estado, a censura e a intervenção oficial em sindicatos e no Congresso Nacional. A abertura teve altos e baixos, evoluindo de forma não-linear. A liberalização era uma briga sem final definido na qual nenhum ator político sabia ao certo como e quando se chegaria a um fim. Assim, o regime militar brasileiro levou dez anos para consolidar-se (1964-1973) e mais quinze para instituir eleiçóes presidenciais universais e competitivas (1974-1989).

Quais eram as dimensôes internacionais da abertura? O ambiente externo apenas jogou um papel secundário, senão irrelevante, na decisão presidencial de abrir o regime em 1974. De fato, a pressão internacional pela democratização somente chegaria três anos mais tarde, com a eleição de Jimmy Carter para o governo norte-americano. Tais pressões, entretanto, tiveram o impacto oposto ao pretendido, levando vários atores domésticos a reagir ao processo de reforma,

Porém, é mister notar que abertura e política externa se interagiram de forma significativa. Ao mudar o foco das indagações das dimensões internacionais da liberalização para, ao contrário, levantar questionamentos sobre a política da política externa brasileira à época, então é possível dizer coisas relevantes sobre a maneira em que a cena internacional e os desenvolvimentos domésticos interagiram naquele momento histórico. Quais foram, então, as dimensões de política externa da abertura? Esta ainda é uma área incipiente do conhecimento que deverá receber atenção detalhada. A título tentativo, e de maneira sintética, é plausível sugerir que a política externa de Geisel foi mais uma das ferramentas utilizadas pelo governo para ganhar controle sobre as facções militares rivais e angariar apoios da opinião pública nacional.

Assim, a política externa foi utilizada de três maneiras principais. Em primeiro lugar, Geisel utilizou o processo decisório da política externa para fortalecer seu controle pessoal sobre seus colegas militares. Ele sabia que ao ganhar batalhas internas contra a linha dura em temas da agenda externa, seu projeto político estaria sendo fortalecido como um todo. 
De tal sorte, quando o presidente decidiu reconhecer os movimentos independentistas marxistas na África Negra e na China comunista, ele lançou ofensiva preventiva no Conselho de Segurança Nacional - uma instituição dominada por militares - para cooptar seus membros. Da mesma maneira, Geisel reestabeleceu os laços com o mundo socialista. Dois eventos tendem a confirmar essa interpretação. Por um lado, quando o principal porta-voz da linha dura, ministro do Exército Sílvio Frota, foi sumariamente demitido por Geisel, seu discurso de renúncia era uma crítica explícita à condução da política externa. Assim, a atuação internacional do Brasil era moeda de troca entre as facçôes do regime. Por outro lado, hoje sabemos que a decisão presidencial de não reestablecer relaçóes formais com a Cuba de Fidel Castro apesar das recomendaçóes de Silveira era motivada pela percepção de que, ao fazê-lo, o grupo do presidente poderia perder a briga que tal movimento necessariamente desencadearia entre os militares. ${ }^{28}$

Em segundo lugar, a política externa foi a principal protagonista de um dos principais passos da abertura - o fim da censura à imprensa. Cedo em seu governo, Geisel decidiu que daria depoimentos durante suas viagens internacionais. Dessa forma, mantinha a mística em torno da figura do chefe de Estado e evitava ter que lidar com o impacto de suas declaraçôes na caserna e na sociedade civil. Repentinamente, as viagens do presidente ao exterior passaram a incluir enviados especiais dos principais jornais e televisões do país. ${ }^{29}$ Embora o interesse dos mesmos não fosse prioritariamente por assuntos da agenda internacional, o clima das viagens e as inovaçôes do governo na pauta externa criaram uma situação na qual a diplomacia era a política governamental mais debatida e, conseqüentemente, mais questionada. Assim, a partir de 1975, encontra-se um número expressivo de artigos de jornal, editoriais e comentários sobre a política externa. Poucas vezes na história um chanceler tinha sido retratado como carnavalesco, perigoso, pouco sério, inconsciente e pueril. ${ }^{30}$ Não surpreende, portanto, que Silveira tenha

\footnotetext{
${ }^{28}$ Ver PINHEIRO, op., cit., e SPEKTOR, op. cit.

${ }^{29}$ Especialmente o Jornal do Brasil (Walder de Góes), a Gazeta Mercantil (Míriam Leitão), O Estado de São Paulo (Carlos Conde), a Folha de São Paulo (Clóvis Rossi), O Globo (Célia Sardemberg) e a Rede Globo (Marilena Chiarelli).

${ }^{30}$ Ver editoriais de Jornal do Brasil, O Estado de São Paulo e Folha de São Paulo do dia $1^{\circ}$ fev 1979.
} 
sido o primeiro chefe do Itamaraty a instituir uma divisão para lidar exclusivamente com a imprensa.

Em terceiro lugar, a política externa foi elemento utilizado por Geisel para gerar consenso doméstico entre as diversas facções da cena política. Por exemplo, ao aumentar o tom terceiro-mundista do discurso diplomático e ao mostrar vigor nas relações com os Estados Unidos, ele compensava o conservadorismo e lento ritmo de suas políticas domésticas. O governo também lançou mão da denúncia nacionalista de normas e padrões internacionais para o meio ambiente e os direitos humanos, protegendo não apenas os interesses da indústria instalada no Brasil, mas também preservando a corporação militar de potenciais acusações pelo aprisionamento político e desaparecimento de civis. Ao fazê-lo, Geisel conseguiu angariar apoios de todo o espectro ideológico, inclusive de setores da esquerda nacionalista que se encontravam excluídos do processo político formal.

Por fim, Geisel chegou ao poder apenas alguns meses após o primeiro choque do petróleo. Durante sua gestão, o mercado creditício internacional para naçóes em desenvolvimento colapsou. Contrariamente à estratégia da Coréia do Sul, perante esse cenário o Brasil aumentou o investimento público em seu programa de industrialização, acreditando que o país atravessava uma fase crítica do desenvolvimento capitalista. O resultado foi amplamente negativo. Em 1974, o Brasil acumulava um déficit comercial de US\$ 4 bilhões. Ao fim do governo Geisel, eram US\$14 bilhōes, uma tendência desconhecida em um país que apresentava superavits sucessivos desde a década de 1860 . Durante seus cinco anos no poder, o crescimento do produto interno bruto caiu de $11 \%$ a $6,8 \%$ ao ano. A dívida externa passou de US\$ 12,5 a US\$ 49 bilhões. ${ }^{31}$ A política externa apenas tinha um papel limitado nesse quadro, mas a situação econômica impunha constrangimentos muito concretos àquilo que o país podia fazer internacionalmente e àquilo que o presidente podia legitimar domesticamente.

\footnotetext{
${ }^{31}$ Ver CARNERIO, Dionísio. Crise e esperança: 1974-1980. In: ABREU, Marcelo de Paiva (ed.). A ordem do progresso: cem anos de política econômica republicana (1889-1989). Rio de Janeiro: Campus, 1992, p. 295-322.
} 
Assim, embora os fatores internacionais não sejam centrais para explicar os porquês da abertura política de Geisel, a política externa cumpriu funçôes importantes naquele projeto e foi por ele condicionada.

\section{A chancelaria de Silveira: mecanismos de implementação}

Silveira, aos 57 anos de idade, era um candidato a chanceler pouco provável à primeira vista. Ao longo de sua carreira, não conseguira apadrinhamentos significativos, ${ }^{32}$ tampouco era uma figura publicamente conhecida cujo prestígio lhe facilitasse a operacionalização da ousada agenda do presidente. O Exército e a Marinha foram abertamente avessos a sua nomeação. ${ }^{33}$ No ministério, o anúncio fez o embaixador Roberto Campos, principal desafeto da vida profissional de Silveira, reagir verbalmente - os ataques pessoais entre ambos estão patentes nas memórias de $u^{34}$ e no depoimento do outro. ${ }^{35}$ Contudo, a postura heterodoxa que Silveira adotara na negociação com Buenos Aires e a decisão presidencial de utilizar a política externa como vitrine da descompressão doméstica apesar do desconforto da "linha dura" faziam dele o homem que Geisel procurava. ${ }^{36}$

Em um contexto em que um sistema político é articulado diretamente pelo presidente, os seus assistentes diretos ganham inusitada capacidade

\footnotetext{
32 Exceção seja feita para o ex-presidente Costa e Silva, que teria defendido o nome de Silveira durante a chancelaria de Juracy Magalhães. Costa e Silva e Silveira haviam feito amizade quando serviram, juntos, na embaixada em Buenos Aires nos anos 40. Depoimento, cassete n. 2, lado A, 10 maio 1979.

33 Depoimento, cassete n. 2, lado B, 10 maio 1979.

${ }^{34}$ De forma geral, pode-se dizer que Campos criticava Silveira por melindrar as relações com os dois eixos fundamentais da política externa brasileira (Argentina e Estados Unidos) e por pensar-se acima de sua estatura política (o que não deixa de ser irônico, dada a baixa estatura física do chanceler). CAMPOS. Lanterna... p. 925 e 1013 e CAMPOS, Roberto. Prefácio. In: BANDEIRA, Moniz. Relaçôes Brasil-... p. 11-17.

${ }^{35}$ Silveira via em Campos a síntese do atraso intelectual que defendera o alinhamento automático à potência hegemônica como saída diplomática para o Brasil contemporâneo. Além disso, rechaçava os métodos que Campos utilizara, em vão, para alcançar a chefia do Itamaraty. Note-se que o fato de Campos ter sido embaixador em Londres durante a gestão Silveira gerou inúmeros atritos entre os dois. Depoimento, cassete n. 2, lado A, 10 maio 1979 e cassete n. 17, lado A, 7 jun. 1979.

${ }^{36}$ Depoimento, cassete n. 11, lado B, 1 jun. 1979. Ver também CAMPOS. Lanterna... p. 925.
} 
de influência sobre os rumos da ação. Quando o mandatário tem interesse em imprimir força pessoal à política externa, seu chanceler encontra-se em uma posição singular na história de uma chancelaria relativamente autônoma em relação a vaivém da política. Assim, Silveira não enfrentou competição, para assuntos internacionais, com nenhum outro ministro ou assessor direto do presidente. ${ }^{37}$ Exceção deve ser feita aos ministros da Fazenda e das Minas e Energia, que tinham ascendência sobre Silveira em questōes econômicas e de petróleo. No último caso, a pasta era ocupada por Shigeaki Ueki, assessor de Geisel desde os anos em que o general comandara a Petrobrás, e ele também tinha palavra sobre os tecnicismos referentes a Itaipu. ${ }^{38}$

Não é possível emitir opinião clara sobre o grau de consciência que Geisel e Silveira tinham das mudanças que se propunham a realizar na política externa brasileira no momento de assumir o governo. Silveira não escrevia suas idéias sobre o tema e recusou-se a fazê-lo quando assim lhe foi solicitado pelo presidente eleito. Não havia um texto de referência ou marco geral para a ação, nem concepções detalhadas sobre qual postura adotar nas diversas frentes. ${ }^{39}$

Em um ambiente internacional flexível, essa característica tendia a fazer de Silveira uma fonte essencial de escolhas no ministério, uma vez que as posturas a adotar eram decididas caso a caso sob a direta supervisão do ministro. Isso era reforçado pelo fato de que, embora Geisel se interessasse por assuntos internacionais, pois a diplomacia foi a pasta mais beneficiada com sua atenção, não há como atribuir-lhe pensamento organizado sobre

\footnotetext{
37 Diferentemente do que reza a doxa, Golbery do Couto e Silva, chefe do Gabinete Civil e principal consiglieri de Geisel, não se aventurou a lidar com a agenda internacional do país, concentrando suas energias no processo de liberalização política. Sua única participação no processo de política externa entre 1974 e 1979 teria sido na última reunião de Gabinete, quando tratou-se sobre o tema de Itaipu, uma vez que seria ele o responsável por conduzir o assunto durante o processo de transição para o novo governo. Depoimento, cassete n. 6, lado A, 18 maio 1979.

${ }^{38}$ A ojeriza de Silveira em relação ao ministro Ueki permeia todo o Depoimento, com destaque para os cassetes n. 14, lado B e 15, lado B, ambos de 7 jun. 1979.

39 Depoimento, cassete n. 1, lado B, 1 maio 1979. Ver também discurso de Silveira por ocasião do Dia do Diplomata em 1974. "A diplomacia nem sempre se presta à formulação de programas rígidos. Não se pode, assim, fazer um elenco de metas ou propor calendários para alcançá-las". BRASIL. Ministério das Relações Exteriores. Resenha de política exterior do Brasil. Brasília: MRE. n.1., mar, abr, maio e jun 1974, p. 30.
} 
o tema. As decisões eram definidas por ambos em conversas pessoais e mediante um intenso sistema de consulta sistemática. ${ }^{40}$

O método de intercâmbio entre Geisel e Silveira é peculiar. O principal vínculo de comunicação entre ambos - as Informaçôes ao presidente da República - era produzido pelo chanceler para uso exclusivo do presidente. Ele percorria essa documentação cuidadosamente, anotando observações e dúvidas ou emitindo opiniōes à mão, prática que relembra a presidência de Vargas.

É possível identificar funçôes-chave para a peça. As Informaçôes eram educativas em forma e conteúdo, esclarecendo os antecedentes dos problemas e apontando possíveis opções ao mandatário. Os arquivos pessoais de Silveira, depositados na Fundação Getúlio Vargas, mostram uma verdadeira coleção de memorandos informativos ao presidente. Dessa forma, Silveira informava o pensamento internacional de Geisel e temperava-lhe as opiniōes. Sendo responsável pela implementação de uma agenda diplomática inovadora, é plausível acreditar que Silveira tenha lançado mão de detalhados e inúmeros relatórios ao presidente sobre estratégia e cálculo tático porque os mesmos serviriam para preservar o próprio chanceler naquele ambiente altamente competitivo. A precaução de Silveira chegou a levá-lo a detalhar até mesmo eventuais entendimentos telefônicos tidos com o presidente, fazendo das Informaçôes um relato completo a respeito dos motivos e da gênese de cada decisão. Por outro lado, as Informaçôes eram um instrumento para consagrar a vontade do chanceler sobre os assuntos externos. Os ministros de Geisel sabiam que seu chefe tinha apreço por reflexóes escritas, assim como sabiam que uma boa justificativa tinha altas chances de ser aceita pelo Planalto sem modificações substanciais. ${ }^{41}$

\footnotetext{
${ }^{40}$ Além da riqueza das informações escritas que Silveira encaminhava a Geisel, sabe-se que tanto o Gabinete do chanceler quanto a sua casa contavam com uma linha telefônica exclusiva da qual apenas o Presidente tinha o número e que não fazia parte da rede de telefones do Palácio do Itamaraty. Depoimento, cassete n. 1, lado B, 1 maio 1979. Note-se também que o número de horas de despacho dedicadas por Geisel a Silveira supera amplamente as do segundo colocado no ministério, o ministro da Justiça, Armando Falcão. Geisel despachou aproximadamente 230 horas com Silveira ao longo de seu mandato, contra 186 com Falcão. Ver FALCÃO, op. cit., p. 251. ${ }^{41}$ GÓES. O Brasil..., p. 30.
} 
Dessa maneira, o paradigma geiseliano de relações externas não foi preconcebido em detalhes pelo presidente e seu chanceler, mas desenvolveu-se paulatinamente à medida em que os desafios e as oportunidades conjunturais se apresentavam. ${ }^{42} \mathrm{O}$ fato de Geisel haver restringido a implementação da política externa ao gabinete de Silveira, sem reuniões gerais ou mesmo consultas informais a outros diplomatas, era certamente um dos principais instrumentos de poder do chanceler. Nesse contexto, o papel do Conselho de Segurança Nacional ${ }^{43}$ era de ritualização de decisões tomadas previamente pelo chefe de Estado. ${ }^{44} \mathrm{~A}$ importância desse mecanismo era a de dar forma às decisões presidenciais, prover explicaçóes causais para as mesmas e legitimá-las face ao grande número de agências do aparelho de Estado. As decisóes ganhavam uma camada protetora que as impermeabilizava diante das críticas da "linha dura" e de setores do Itamaraty, preservando a imagem pessoal de Geisel contra eventuais ataques da imprensa.

O respaldo certeiro do Planalto permitiu a Silveira não apenas implementar a agenda que os dois ambicionavam, gozando de certa autonomia face ao resto das agências governamentais, mas também assegurou ao ministro o salvo-conduto para encaminhar a reestruturação interna de sua própria corporação. Silveira era cético a respeito da capacidade criativa dos diplomatas brasileiros. ${ }^{45}$ A sua crítica era de cunho weberiano e nada tinha de inusitada: as agências burocráticas tendem a tornar-se meras reprodutoras de procedimentos formais, gerando incentivos naturais para soluções de compromisso em que todos apóiam determinada decisão por menos satisfatória que seja e ninguém

\footnotetext{
42 Para uma contextualização crítica dessa política, ver MELO, Ovídio de. Op. cit.

43 O Conselho era um plenário onde tinham assento todos os ministros de Estado, o vicepresidente da República, o chefe do Estado Maior das Forças Armadas e os chefes do EstadoMaior do Exército, da Marinha e da Aeronáutica. Dispunha de uma Secretaria Geral (ocupada pelo ministro da Casa Militar), que realizava estudos, planejamento e coordenação no campo da segurança nacional, com poder de requisitar serviços de quaisquer órgãos da administração pública. No tempo de Geisel, contava com aproximadamente 130 funcionários, dos quais apenas 26 eram especialistas em suas áreas de atuação. GÓES. O Brasil... p. 33 e 38. Para uma análise detalhada do papel do Conselho de Segurança Nacional, em política externa, à época de Geisel, ver PINHEIRO. Op. cit.

${ }^{44}$ GÓES. O Brasil..., p. 29.

45 Depoimento, cassetes n. 3, lado B, 15 maio 1979, e 18, lado A, 29 jan. 1980.
} 
se responsabiliza diretamente por suas conseqüências. Operacionalmente, essa vertente está consubstanciada no mecanismo dos sucessivos "vistos" departamentais tão comuns nas chancelarias modernas e extensamente utilizado no Itamaraty. $\mathrm{O}$ outro lado da moeda, nesse caso, é que essa diluição da responsabilidade dos setores é um dos elementos sobre os quais se assentam as bases do espírito de corpo que faz da chancelaria uma agência singular no seio do Estado brasileiro.

Isso não significa que Silveira fosse um advogado do risco como elemento perene da diplomacia. Ao contrário, pensava que, se por um lado, os diplomatas tendiam a arriscar-se menos do que os outsiders, por outro também cometiam menos erros em seus cálculos, ${ }^{46}$ o que compensava de certa forma a lentidão e a falta de espaço para a criatividade individual em um processo decisório estruturado sobre consensos consecutivos. Contudo, o ministro estava seguro de que pouquíssimos membros da carreira estavam capacitados para pensar efetivamente as relações internacionais do Brasil. Em sua opinião, as limitaçôes da maioria do pessoal do ministério haviam levado o Brasil a perder oportunidades e insistir em posições obsoletas. ${ }^{47}$ Era essa falta de ousadia que lhe perturbava, e contra ela trabalhou por meio de quatro mecanismos identificados ao longo deste estudo. Há indícios de que alguns deles foram concebidos antes mesmo da posse, enquanto outros foram sendo implementados à medida que sua gestão avançava.

Em primeiro lugar, procurou associar-se a personalidades reconhecidamente inovadoras do próprio ministério, ganhando com isso fôlego para enfrentar a legião de "especialistas" que denunciariam o excesso de riscos aos quais a diplomacia incorreria. Embora não pertencesse a nenhuma vertente intelectual particular dentro do Itamaraty, ou mesmo a um grupo específico, Silveira associou-se a Araújo Castro ${ }^{48}$ e Ítalo

\footnotetext{
46 Depoimento, cassete n.3, lado B, 15 maio 1979.

47 Depoimento, cassete n. 1, lado B, 15 maio 1979.

48 João Augusto de Araújo Castro foi ministro interino das Relações Exteriores em 1963, embaixador em Atenas (1964-1966), embaixador em Lima (1966-1967), chefe da Missão junto às Naçôes Unidas (1968-1971) e embaixador em Washington (1971-1975). Destacou-se por ser crítico ao princípio do alinhamento automático aos Estados Unidos na década de 1960 e por desenvolver a tese do "congelamento do poder mundial", segundo a qual o programa soviéticoestadunidense de controle internacional de armamentos era deletério às naçôes de porte médio por estender indefinidamente uma situação de desigualdade entre as nações. Durante o golpe
} 
Zappa ${ }^{49}$ duas vozes destoantes da doxa corporativa no início da década de 1970, que advogavam pela renovação do perfil da ação do Itamaraty em direção a maiores graus de autonomia face a Washington.

Em segundo lugar, transformou seu gabinete no centro de comando de todo o ministério, tomando decisões sem necessariamente atravessar todas as etapas de consulta tradicionais de uma chancelaria complexa e relativizando a importância da Secretaria-Geral na definição de vetores resultantes. É possível que essa tática tenha sido utilizada para aumentar a dependência de todos os setores em relação às decisões do próprio ministro, para assegurar que os trâmites burocráticos não atrapalhassem o ritmo de implementação da agenda, ou ainda para evitar que a visão de Silveira sobre casos específicos fosse influenciada.

Em terceiro lugar, o chanceler fez uma clara opção por rejuvenescer os postos-chave do ministério. Além de promover os mais moços para diversas chefias e cadeiras de confiança no gabinete, procurou expandir essa orientação para os comandos de embaixadas em vários países. ${ }^{50}$ Curiosamente, essa última iniciativa foi o principal ponto de discordância entre o ministro e o presidente, uma vez que Geisel suspeitava de que o envio de embaixadores jovens para postos de alta importância poderia gerar desconforto, especialmente em Buenos Aires e Washington. ${ }^{51}$ Mas a renovação de postos atingiu em cheio seu gabinete e as estruturas que dependiam diretamente do contato cotidiano com o chanceler. Silveira

militar de 1964, foi acusado de praticar ações comunistas e, com a mediação de Silveira, foi enviado para a embaixada em Atenas. Depoimento, cassete n. 5, lado A, 18 maio 1979. Sobre ele, ver AMADO, R. Araújo Castro. Brasília: Editora Universidade de Brasília, 1982.

49 Ítalo Zappa foi chefe do Departamento da África, Ásia e Oceania do Itamaraty durante a primeira metade da gestão Silveira e, em seguida, embaixador em Maputo (1977-1981). Esteve no centro da estratégia de redefinição da política africana do Brasil, consubstanciada nos apoios oferecidos às independências africanas em Angola e Guiné-Bissau (1974) e o reconhecimento da independência de Moçambique (1975) a despeito da orientação marxista desses movimentos. Ver Pinheiro, op. cit., p. 275. Ver, dele, ZAPPA, Ítalo. Nova ordem mundial: aspectos políticos. Revista Brasileira de Politica Internacional, a. 18, n. 69/72, p. 83-88, 1975.

${ }^{50}$ Durante o qüinqüênio em que comandou o Itamaraty, Silveira renovou dois terços dos postos. Em 1979, ao finalizar a sua gestão, havia ministros que tinham entre 28 e 45 anos e embaixadores de 50 anos, fenômeno inusitado na vida da corporação. Depoimento, cassete n. 3, lado B, 15 maio 1979.

${ }^{51}$ Depoimento, cassete n. 2, lado B, 10 maio 1979. Ver, também, Presidente influi nas promoções. O Estado de S. Paulo, 11 maio 1977, s/p. 
trouxe ou vinculou ao gabinete jovens profissionais que considerava brilhantes e que podiam seguir seu ritmo: "Eu precisava ter olhos e mãos que funcionassem para mim, que pudessem ter diálogo conceitual comigo". ${ }^{52}$ Esses jovens eram responsáveis não somente por selecionar e responder a correspondência, cuidar da agenda e funcionar como memória institucional do gabinete, mas também por fazer estudos encomendados diretamente por Silveira, os quais serviriam de base intelectual para a definição de riscos e oportunidades. ${ }^{53}$ Eles foram logo batizados de Silveira's Boys, e mantiveram-se influentes no ministério por mais de três décadas. ${ }^{54}$

$\mathrm{O}$ ministro promoveu ainda um quarto mecanismo a fim de impedir a estagnação da capacidade inovadora da chancelaria. Tratava-se de um sistema piloto de intercâmbio de reflexões entre as embaixadas e o ministro, relegando a um segundo plano as tradicionais correspondências de caráter meramente informativo. $\mathrm{O}$ mesmo funcionaria em forma de correspondências secretas e devia ser "não rotineiro, moderno e criador (...) que possa gerar elementos para o planejamento global de médio prazo da política externa" e retirar o "enciclopedismo infelizmente comum na execução das tarefas de informação por parte das Missões Diplomáticas". 55 Sabe-se que esse sistema foi efetivamente implantado para a embaixada em Buenos Aires e outras duas que não foram identificadas na análise documental.

\section{Conclusão}

Este artigo apontou os antecedentes intelectuais e materiais, as tensões de origem e os primeiros mecanismos institucionais de implementação do Pragmatismo Ecumênico e Responsável (1974-1979).

\footnotetext{
${ }^{52}$ Depoimento, cassete n. 5, lado A.

53 Depoimento, cassete n. 2, lado A, 10 maio 1979.

${ }^{54}$ Faziam parte do grupo: Luiz Felipe Lampreia, Paulo Roberto Bertel Rosa, José Nogueira Filho, Gilberto Velloso, Marcos César Naslausky, Alcides da Costa Guimarães, Rene Agnauer, Celina Assunção, Jorge Carlos Ribeiro, Sérgio Duarte, Guy Brandão e Ronaldo Sardemberg.

55 MRE à legação em Buenos Aires, ofício secreto, Brasília, 20 dez 1976, n. 1702, AHMRE, caixa 42 .
} 
Em primeiro lugar, situou-se a emergência da noção brasileira de pragmatismo no campo do pensamento político realista. Procurou-se, ainda, evidenciar de que maneira as tradições do realismo político e da política externa nacional articularam-se ao longo da década prévia ao governo Geisel.

Na seqüência, o trabalho ofereceu uma interpretação sobre a trajetória e o pensamento realista de Azeredo da Silveira mediante a recuperação das táticas por ele utilizadas para lidar com a Argentina durante sua gestão como embaixador em Buenos Aires (1969-1974).

$\mathrm{O}$ trabalho também buscou contextualizar a política externa do pragmatismo no marco do projeto político do presidente Geisel de liberalização do regime autoritário. Desde suas origens, o pragmatismo teve que ser legitimado perante uma platéia doméstica variada: a linha dura e as linhas moderadas do regime militar, uma opinião pública cada vez mais livre para discordar da conduta governamental e grupos de interesse com capacidade de vocalização de demandas. De tal sorte, o esforço empreendido pelo governo para legitimar as suas opções de política externa incluíram um conjunto de táticas discursivas, estratégias de imprensa e medidas administrativas. Finalmente, tratou-se de evidenciar os primeiros efeitos organizacionais do pragmatismo na estrutura e métodos de trabalho do Ministério das Relações Exteriores.

Novembro de 2004

\section{Resumo}

Ao longo de seu governo, o presidente Geisel e seu chanceler, Azeredo da Silveira, promoveram mudanças sistemáticas na política externa do país sob a égide do Pragmatismo Ecumênico e Responsável (1974-1979). O programa buscava projetar o Brasil na hierarquia internacional de poder, tirando vantagens de um sistema internacional singularmente flexível. Sua lógica articulou aspectos tradicionais da política externa brasileira com elementos típicos do realismo político. Este artigo utiliza fontes recentemente disponibilizadas para interpretar os antecedentes, origens e tensões iniciais da noção de pragmatismo. 


\section{Abstract}

In the mid-1970s the Brazilian government introduced systematic changes in Brazilian foreign policy on the basis of an Ecumenical, Responsible Pragmatism. Their main thrust was to facilitate and foster the emergence of Brazil as a middle power in what was seen as a uniquely malleable international system. Brazilian officials made a conscious attempt to reconcile their own foreign policy traditions with notions typical of political realism. This article draws on recently declassified documents to account for the preconditions, origins and initial tensions of pragmatism.

Palavras-chave: Política externa do Brasil, Potência emergente, Regime militar, Pragmatismo, Realismo, Ernesto Geisel, Antônio Francisco Azeredo da Silveira.

Key-words: Brazilian foreign policy; emerging power; authoritarian rule; pragmatism; realism; Ernesto Geisel; Antônio Francisco Azeredo da Silveira. 